\title{
Hospital admissions due to ambulatory care sensitive conditions among children by age group and health region*
}

\author{
Hospitalizações sensíveis à atenção primária em crianças, \\ segundo grupos etários e regionais de saúde \\ Hospitalizaciones sensibles a la atención primaria en niños, \\ según los rangos de edad y las regionales de salud
}

Kelly Holanda Prezotto ${ }^{1}$, Maria Marta Nolasco Chaves ${ }^{2}$, Thais Aidar de Freitas Mathias ${ }^{3}$

\footnotetext{
* Taken from the dissertation "Hospitalizações por condições sensíveis à atenção primária em crianças menores de cinco anos, Paraná, 2000 a 2011", Postgraduate nursing programme at the State University of Maringá, 2013.

${ }^{1}$ Professor of the Nursing Department, Centre of Biological Sciences at the State University of the North of Paraná, Bandeirantes, Paraná, Brasil.

${ }^{2}$ Professor of the Nursing Department, Department of Health Sciences at the Federal University of Paraná, Curitiba, Paraná, Brasil.

${ }^{3}$ Professor of the Nursing Department, Department of Health Sciences at the State University of Maringá, Maringá, Paraná, Brasil.
}

\begin{abstract}
Objective: to describe hospital admissions for ambulatory care sensitive conditions in children under five years of age in the State of Paraná, Brazil by condition type, age group and health region. Method: a temporal ecological study was conducted using data from the Unified Health System Hospital Information System for the period 2000 to 2011. Conditions were grouped in accordance with the list of ambulatory care sensitive conditions in Brazil. Results: there was an increase in the rate of admissions for ambulatory care sensitive conditions in all age groups in $50 \%$ of the health regions, with a marked increase in children under the age of one. Pneumonia, gastroenteritis and asthma were the main causes of admissions. There was an increase in the proportion of overall admissions accounted for by pneumonia and gastroenteritis. Conclusion: the increase in admissions reveals the need for actions to improve access to primary healthcare and provide effective treatment of the main ambulatory care sensitive conditions in order to prevent hospital admissions among children.
\end{abstract}

\section{DESCRIPTORS:}

Child; Hospitalization; Primary Health Care; Information Services; Child Health.
Correspondence Addressed to:

Kelly Holanda Prezotto

Setor de Enfermagem,

Centro de Ciências Biológicas,

Universidade Estadual do Norte do Paraná

Rodovia BR-369, Km 54, Vila Maria

CEP 86360-000 - Bandeirantes, PR, Brasil

E-mail: kelly.prezotto@uenp.edu.br
Received: 08/25/2014

Approved: 11/21/2014 


\section{INTRODUCTION}

A number of advances have been made in primary health care (PHC) since the creation of Brazil's Unified Health System (SUS), principally due to the decentralisation of management functions and responsibilities. The current debate about the implementation of healthcare networks in Brazil emphasises the pivotal role that PHC plays in the health system and in achieving the continuity and comprehensiveness of care and effective solution of health problems ${ }^{(1)}$.

A growing number of studies aim to measure the effectiveness of PHC by analysing indicators ${ }^{(2-3)}$ used to guide actions and evaluate the determinants of the health-disease process ${ }^{(4)}$. One potential indicator is hospital admissions for ambulatory care sensitive conditions (ACSC admissions) ${ }^{(5-6)}$.

ACSC admissions can be avoided by preventative care and the early diagnosis and treatment of diseases, and are used to measure access to health services and the effectiveness of primary care ${ }^{(7)}$. The list of ACSCs in Brazil is organised in 19 groups and based on the International Classification of Diseases (ICD-10) ${ }^{(8)}$.

Any analysis of ACSC admissions needs to consider population variables such as age. Data should therefore be analysed by age group to obtain a better understanding of the phenomenon in question ${ }^{(9)}$ and studies of ACSC ad- missions among children demonstrate the potential of indicators resulting from this type of analysis $(6,10)$.

A study in Brazil showed that the main causes of ACSC admissions among children aged between one and four were gastroenteritis, asthma and pneumonia ${ }^{(6)}$, while a study of three municipalities in the Northeast region of the State of Paraná carried out between 1998 and 2009 observed that the two principal causes were respiratory tract diseases $(55.6 \%)$ and infectious and parasitic diseases $(14.8 \%)^{(2)}$.

Each stage of growth and development presents different health and disease challenges. However, there is a lack of research on the main types of ACSCs in each stage of child development. Therefore, identifying the types of ACSCs and their effect on hospital admissions among children under the age of five by region can help assess the impact of primary health care and guide interventions that contribute towards a reduction in potentially avoidable admissions among this group.

Given the above and the importance of research to guide primary health care interventions with a special focus on children, this study aims to outline the essential features of ACSC admissions among children under the age of five in the State of Paraná by analysing data obtained for the period 2000 to 2011, according to age group, admitting diagnosis, and place of residence (health region and macro-region).

Chart 1 - List of ambulatory care sensitive conditions in Brazil in 2008.

\begin{tabular}{|c|c|}
\hline ICSAP Group & CID-10 Code \\
\hline 1. Vaccine-preventable diseases and sensitive conditions & $\begin{array}{l}\text { A33-A37, A95, B16, B05-B06, B26, G00.0, A17.0, A19, A15-A16, A18, } \\
\text { A17.1-A17.9, I00-I02, A51-A53, B50-B54 e B77 }\end{array}$ \\
\hline 2. Infectious gastroenteritis and complications & E86 e A00-A09 \\
\hline 3. Anaemia & D50 \\
\hline 4. Nutritional deficiencies & E40-E46 e E50-E64 \\
\hline 5. Ear, nose and throat infections & H66, J00-J03, J06 e J31 \\
\hline 6. Bacterial pneumonia & J13-J14, J15.3-J15.4, J15.8-J15.9 e J18.1 \\
\hline 7. Asthma & J45-J46 \\
\hline 8. Lower respiratory tract infection & $\mathrm{J} 20, \mathrm{~J} 21, \mathrm{~J} 40-\mathrm{J} 44$ e J47 \\
\hline 9. Hypertension & I10-I11 \\
\hline 10. Angina & 120 \\
\hline 11. Heart failure & 150 e J81 \\
\hline 12. Cerebrovascular diseases & I63-167, I69 e G45-G46 \\
\hline 13. Diabetes mellitus & E10-E14 \\
\hline 14. Epilepsy & G40-G41 \\
\hline 15. Kidney and urinary tract infection & N10-N12, N30, N34 e N39.0 \\
\hline 16. Skin and subcutaneous tissue infections & A46, L01-L04 e L08 \\
\hline 17. Pelvic inflammatory disease & N70-N73 e N75-N76 \\
\hline 18. Gastric ulcer & K25-K28, K92.0, K92.1 е K92.2 \\
\hline 19. Prenatal and birth-related diseases & O23, A50 e P35.0 \\
\hline
\end{tabular}

Source: Executive Order № 221, 17th April 2008 (8).

\section{METHOD}

A temporal ecological study was conducted of all hospital admissions occurring between 2000 and 2011 among children under the age of five living in the State of Paraná.
Admission and population data from the Unified Health System Hospital Information System (SIH-SUS, acronym in Portuguese) and Brazilian Institute of Geography and Statistics (IBGE, acronym in Portuguese) was obtained from the Unified Health System data portal (www.datasus. gov.br). This system comprises the main source of informa- 
tion regarding admissions to public hospitals in Brazil and is based on information contained in the hospital admission authorisation form, including personal details, principal and secondary diagnoses, and description of the procedures undertaken during the patient's stay in hospital ${ }^{(11)}$.

The type of ACSC was selected from the list of ACSCs in Brazil ${ }^{\left({ }^{(8)}\right.}$ which is based on the International Classification of Diseases (ICD-10) as shown in Chart 1.

To obtain a better understanding of admissions in each stage of childhood, data was categorised into the following age groups: under one year (up to 11 months and 29 days); one to two years (from 12 months to 35 months and 29 days), and three to four years (36 months to 59 months and 29 days). The years were grouped into three-year periods: 2000-2002; 2003-2005; 2006-2008, and 2009-2011 to minimise possible yearly fluctuations.

The health region and macro-region for each case was obtained from the code for the municipality of residence mentioned on the hospital admission authorisation form. The State of Paranás 399 municipalities are divided into 22 health regions which in turn are grouped into six macro-regions: East, Campos Gerais, North, Northwest, West and Central-South.

The primary data base consisted of all admissions in Paraná during the study period $(n=9,343,081)$, while the secondary data base was made up of all admissions of children under the age of five years $(n=819,939)$. Cases requiring an extension of hospital stay $(n=93)$ and children not resident in the State of Paraná $(n=6,616)$ were excluded, resulting in a final sample size of 813,230 .

A comparison was made between the ICD-10 code recorded in the principal diagnosis field of the hospital admission authorisation form and the ICD-10 codes in the list of ACSCs in Brazil to determine whether the principal diagnosis was an ACSC. The cases were then classified as ambulatory care-sensitive or nonambulatory care-sensitive and coded based on the list of ACSCs in Brazil.

Two indicators were used for the analysis: rate of admissions due to ACSC as a proportion of total admissions (total number of ACSC admissions divided by the overall number of admissions in the age group and year of occurrence multiplied by 100); overall admission rate per inhabitant (overall number of admissions due to ambulatory care-sensitive and non-ambulatory care-sensitive conditions divided by the total number of children resident, according to age, year of occurrence, and place of residence, multiplied by 10,000).

With respect to the overall admission rate, the percentage variation between the first and last three-year period was calculated by subtracting the rate of the last period, multiplied by 100 and divided by the rate of the first period, from 100. The programs Excel and Statistical Package for the Social Sciences - SPSS 18.0 were used to organise and analyse the data.

\section{RESULTS}

A total of 813,230 admissions of children under five years of age were registered by the SIH-SUS, of which $82,636(10.2 \%)$ were due to ACSCs. The data shows that the proportion of ACSC admissions was greatest among children between one and two years of age $(55,038$ out of a total of 458,696 admissions were due to ACSCs $=12 \%)$, and lowest in children under one year of age ( 873 out of a total of 81,918 admissions were due to ACSCs $=1.1 \%)$. The proportion of ACSC admissions and admission rate increased in each age group between the first and last three-year period (Table 1).

Table 1 - Proportion of ACSC admissions and rate of admissions due to ambulatory care sensitive or nonambulatory care sensitive conditions for each three-year period. Paraná, 2000 to 2011.

\begin{tabular}{|c|c|c|c|c|c|c|c|c|c|}
\hline \multirow{2}{*}{ Cause } & \multicolumn{2}{|c|}{ 2000-2002 } & \multicolumn{2}{|c|}{ 2003-2005 } & \multicolumn{2}{|c|}{ 2006-2008 } & \multicolumn{2}{|c|}{ 2009-2011 } & \multirow{2}{*}{$\begin{array}{c}\begin{array}{l}\text { Variation \% } \\
00 / 02-09 / 11\end{array} \\
\text { Rate } \\
\end{array}$} \\
\hline & $\%$ & Rate & $\%$ & Rate & $\%$ & Rate & $\%$ & Rate & \\
\hline & \multicolumn{9}{|c|}{ Under one year } \\
\hline Non-ambulatory care-sensitive & 99,4 & 360,5 & 98,8 & 347,7 & 98,8 & 427,5 & 98,7 & 522,1 & 44,8 \\
\hline Ambulatory care-sensitive & 0,6 & 2,2 & 1,2 & 4 & 1,2 & 5,1 & 1,3 & 6,6 & 200 \\
\hline \multirow[t]{2}{*}{ Total } & 100 & 362,7 & 100 & 351,7 & 100 & 432,6 & 100 & 528,8 & 45,8 \\
\hline & \multicolumn{9}{|c|}{ One to two years } \\
\hline Non-ambulatory care-sensitive & 90,4 & 1200,4 & 86,5 & 941,9 & 86,5 & 915,5 & 88,1 & 952,3 & $-20,7$ \\
\hline Ambulatory care-sensitive & 9,6 & 127,1 & 13,5 & 147,4 & 13,5 & 143,4 & 11,9 & 128,7 & 1,3 \\
\hline \multirow[t]{2}{*}{ Total } & 100 & 1327,5 & 100 & 1089,3 & 100 & 1058,9 & 100 & 1081 & $-18,6$ \\
\hline & \multicolumn{9}{|c|}{ Three to four years } \\
\hline Non-ambulatory care-sensitive & 92,4 & 656,5 & 88,8 & 539,3 & 89,2 & 524,5 & 89,9 & 594,1 & $-9,5$ \\
\hline Ambulatory care-sensitive & 7,6 & 54,1 & 11,2 & 67,8 & 10,8 & 63,5 & 10,1 & 66,4 & 22,7 \\
\hline \multirow[t]{2}{*}{ Total } & 100 & 710,6 & 100 & 607,1 & 100 & 588 & 100 & 660,5 & $-7,1$ \\
\hline & \multicolumn{9}{|c|}{ Under five years } \\
\hline Non-ambulatory care-sensitive & 91,8 & 813,1 & 88,4 & 659,8 & 88,7 & 659,1 & 90,1 & 719,3 & $-11,5$ \\
\hline Ambulatory care-sensitive & 8,2 & 72,8 & 11,6 & 86,6 & 11,3 & 83,7 & 9,9 & 78,9 & 8,4 \\
\hline Total & 100 & 885,9 & 100 & 746,3 & 100 & 742,8 & 100 & 798,2 & $-9,9$ \\
\hline
\end{tabular}

Source: Brazilian Ministry of Health. Unified Health System Hospital Information System. DATASUS. 
Table 1 shows that the greatest increase in the proportion of ACSC admissions was in the under one age group $(200 \%)$, while the increase in the under five age group was only $8.4 \%$.

The following four ambulatory care sensitive conditions were not registered among the sample: anaemia, angina, epilepsy and pelvic inflammatory disease.
Bacterial pneumonia and gastroenteritis account for the largest proportion of admissions across all age groups. The third most common disease was diabetes mellitus which was the cause in $12.8 \%$ of children under the age of one admitted to hospital due to a ACSC. The main type of ACSC among children in the one to two year and three to four year age groups was asthma (Table 2).

Table 2 - Number and proportion of ambulatory care sensitive conditions by type of condition and age group. Paraná, 2000 to 2011.

\begin{tabular}{|c|c|c|c|c|c|c|c|c|}
\hline \multirow{2}{*}{ Ambulatory care sensitive condition } & \multicolumn{2}{|c|}{$<1$ year } & \multicolumn{2}{|c|}{1 to 2 years } & \multicolumn{2}{|c|}{3 to 4 years } & \multicolumn{2}{|c|}{$<5$ years } \\
\hline & $\mathbf{N}$ & $\%$ & $\mathbf{N}$ & $\%$ & $\mathbf{N}$ & $\%$ & $\mathbf{N}$ & $\%$ \\
\hline Vaccine-preventable diseases & 7 & 0,8 & 185 & 0,3 & 145 & 0,5 & 337 & 0,4 \\
\hline Infectious gastroenteritis & 116 & 13,3 & 19996 & 36,3 & 9431 & 35,3 & 29543 & 35,8 \\
\hline Nutritional deficiencies & 42 & 4,8 & 2584 & 4,7 & 816 & 3,1 & 3442 & 4,2 \\
\hline Ear, nose and throat infections. & - & - & 8 & - & 3 & - & 11 & - \\
\hline Bacterial pneumonia & 287 & 32,9 & 22832 & 41,5 & 10116 & 37,9 & 33235 & 40,2 \\
\hline Asthma & 41 & 4,7 & 4698 & 8,5 & 2928 & 11 & 7667 & 9,3 \\
\hline Lung diseases & 10 & 1,1 & 904 & 1,7 & 464 & 1,7 & 1378 & 1,6 \\
\hline Hypertension & 36 & 4,1 & 43 & 0,1 & 48 & 0,2 & 127 & 0,1 \\
\hline Heart failure & 5 & 0,6 & 18 & - & 6 & - & 29 & - \\
\hline Cerebrovascular diseases & 13 & 1,5 & 57 & 0,1 & 41 & 0,2 & 111 & 0,1 \\
\hline Diabetes mellitus & 112 & 12,8 & 286 & 0,5 & 323 & 1,2 & 721 & 0,9 \\
\hline Kidney and urinary tract infection. & 103 & 11,8 & 2835 & 5,2 & 2065 & 7,7 & 5003 & 6,1 \\
\hline Skin infections & 9 & 1 & 421 & 0,8 & 220 & 0,8 & 650 & 0,8 \\
\hline Gastric ulcer & 4 & 0,5 & 120 & 0,2 & 91 & 0,3 & 215 & 0,3 \\
\hline Congenital rubella syndrome. & 88 & 10,1 & 51 & 0,1 & 28 & 0,1 & 167 & 0,2 \\
\hline Total & 873 & 100 & 55038 & 100 & 26725 & 100 & 82636 & 100 \\
\hline
\end{tabular}

Source: Brazilian Ministry of Health. Unified Health System Hospital Information System. DATASUS.

An analysis of the five main causes of admission over each three-year period revealed that the proportion of admissions accounted for by nutritional deficiencies and asthma decreased by $63.3 \%$ and $23.4 \%$, respectively, among children in the one to two year age group, and by $60.9 \%$ and $28.7 \%$, respectively, in children in the three to four year age group. However, there was an increase in the proportion of admissions accounted for by diabetes mellitus among the under one year age group, and by bacterial pneumonia, gastroenteritis and kidney and urinary tract infection in all age groups (Table 3 ).

Table 3 - Number and proportion of admissions by condition type, age group and three-year period. Paraná, 2000 to 2011.

\begin{tabular}{|c|c|c|c|c|c|c|c|c|c|}
\hline \multirow{2}{*}{ Diagnosis } & \multicolumn{2}{|c|}{ 2000-2002(a) } & \multicolumn{2}{|c|}{ 2003-2005 } & \multicolumn{2}{|c|}{ 2006-2008 } & \multicolumn{2}{|c|}{ 2009-2011(b) } & \multirow{2}{*}{$\frac{\text { Variation (\%) }}{\text { (b-a) }}$} \\
\hline & $\mathbf{N}$ & $\% *$ & $\mathbf{N}$ & $\% *$ & $\mathbf{N}$ & $\% *$ & $\mathbf{N}$ & $\% *$ & \\
\hline & \multicolumn{9}{|c|}{ Under one year } \\
\hline Bacterial pneumonia & 42 & 0,22 & 84 & 0,44 & 84 & 0,4 & 77 & 0,34 & 54,5 \\
\hline Gastroenteritis & 22 & 0,12 & 24 & 0,12 & 39 & 0,19 & 31 & 0,14 & 16,7 \\
\hline Diabetes mellitus & 12 & 0,06 & 14 & 0,07 & 32 & 0,15 & 54 & 0,24 & 300 \\
\hline Kidney and urinary tract infection & 8 & 0,04 & 19 & 0,1 & 27 & 0,13 & 49 & 0,22 & 450 \\
\hline Congenital rubella syndrome & 8 & 0,04 & 56 & 0,29 & 18 & 0,09 & 6 & 0,03 & -25 \\
\hline \multirow[t]{2}{*}{ Total } & 92 & 0,49 & 197 & 1,02 & 200 & 0,95 & 217 & 0,95 & 93,9 \\
\hline & \multicolumn{9}{|c|}{ One to two years } \\
\hline Bacterial pneumonia & 4274 & 3,05 & 7824 & 6,52 & 6443 & 6,05 & 4291 & 4,66 & 52,8 \\
\hline Gastroenteritis & 5775 & 4,12 & 5084 & 4,24 & 5260 & 4,94 & 3877 & 4,21 & 2,2 \\
\hline Asthma & 1320 & 0,94 & 1655 & 1,38 & 1063 & 1 & 660 & 0,72 & $-23,4$ \\
\hline Kidney and urinary tract infection & 546 & 0,39 & 661 & 0,55 & 692 & 0,65 & 936 & 1,02 & 161,5 \\
\hline Nutritional deficiencies & 1102 & 0,79 & 723 & 0,6 & 488 & 0,46 & 271 & 0,29 & $-63,3$ \\
\hline
\end{tabular}




\begin{tabular}{|c|c|c|c|c|c|c|c|c|c|}
\hline \multirow{2}{*}{ Diagnosis } & \multicolumn{2}{|c|}{ 2000-2002(a) } & \multicolumn{2}{|c|}{ 2003-2005 } & \multicolumn{2}{|c|}{ 2006-2008 } & \multicolumn{2}{|c|}{ 2009-2011(b) } & \multirow{2}{*}{$\begin{array}{c}\text { Variation }(\%) \\
(b-a)\end{array}$} \\
\hline & $\mathbf{N}$ & $\% *$ & $\mathbf{N}$ & $\% *$ & $\mathbf{N}$ & $\% *$ & $\mathbf{N}$ & $\% *$ & \\
\hline & \multicolumn{9}{|c|}{ Under one year } \\
\hline \multirow[t]{2}{*}{ Total } & 13017 & 9,28 & 15947 & 13,3 & 13946 & 13,1 & 10035 & 10,91 & 17,6 \\
\hline & \multicolumn{9}{|c|}{ Three to four years } \\
\hline Bacterial pneumonia & 1949 & 2,47 & 3364 & 4,78 & 2705 & 4,26 & 2098 & 3,51 & 42,1 \\
\hline Gastroenteritis & 2211 & 2,8 & 2467 & 3,51 & 2532 & 3,99 & 2221 & 3,72 & 32,9 \\
\hline Asthma & 802 & 1,01 & 1061 & 1,51 & 632 & 1 & 433 & 0,72 & $-28,7$ \\
\hline Kidney and urinary tract infection & 399 & 0,5 & 526 & 0,75 & 511 & 0,8 & 629 & 1,05 & 110 \\
\hline Nutritional deficiencies & 363 & 0,46 & 199 & 0,28 & 148 & 0,23 & 106 & 0,18 & $-60,9$ \\
\hline
\end{tabular}

* Proportion of the total number of admissions due to all causes in each age group and three-year period.

Source: Brazilian Ministry of Health. Unified Health System Hospital Information System. DATASUS.

The proportion of hospital admissions among chil- in the proportion of ACSCs admissions was registered dren under five years of age across the State of Paraná in 11 of the 22 health regions in the state. The largest accounted for by ACSCs increased from $8.2 \%$ in the first increase (615.9\%) was observed in the Maringá health three-year period to $9.9 \%$ in the last period. An increase region (Table 4).

Table 4 - Proportion of ACSC admissions and hospital admission rate (per 10,000 inhabitants) among children under five years of age by health region and macro-region and three-year period. Paraná, 2000 to 2011.

\begin{tabular}{|c|c|c|c|c|c|c|c|c|c|}
\hline \multirow{2}{*}{ Macro-region/health region } & \multicolumn{2}{|c|}{ 2000-2002(a) } & \multicolumn{2}{|c|}{ 2003-2005 } & \multicolumn{2}{|c|}{ 2006-2008 } & \multicolumn{2}{|c|}{$2009-2011^{(b)}$} & \multirow{2}{*}{$\begin{array}{c}\begin{array}{c}\text { Variation } \\
(\%) \text { b-a }\end{array} \\
\text { Rate }\end{array}$} \\
\hline & $\% *$ & Rate & $\% *$ & Rate & $\% *$ & Rate & $\% *$ & Rate & \\
\hline WEST & 6,1 & 43,9 & 9,4 & 56,2 & 9,3 & 55,6 & 5,6 & 40,7 & $-7,1$ \\
\hline Paranaguá & 10,4 & 85,7 & 17,1 & 115,6 & 20,7 & 121,7 & 9,9 & 63,4 & -26 \\
\hline Curitiba & 5,3 & 37,6 & 8,3 & 48,8 & 8,1 & 47,8 & 5,1 & 37 & $-1,7$ \\
\hline União da Vitória & 10,5 & 80,6 & 11,9 & 84,7 & 12,4 & 84,4 & 10,5 & 72 & $-10,7$ \\
\hline CAMPOS GERAIS & 4,2 & 37 & 5,5 & 42 & 6,1 & 42,8 & 8,6 & 61,2 & 65,3 \\
\hline Ponta Grossa & 2,8 & 26,3 & 4,4 & 35 & 5,1 & 36,5 & 7,2 & 51 & 93,5 \\
\hline Irati & 7,2 & 55,2 & 8,4 & 54,9 & 7,6 & 48,9 & 6,9 & 49,7 & $-10,1$ \\
\hline Telêmaco Borba & 6,9 & 54,9 & 7,4 & 53,4 & 7,9 & 57,9 & 14,1 & 103,5 & 88,6 \\
\hline CENTRAL-SOUTH & 20,4 & 235,2 & 17,3 & 172,7 & 13,7 & 150 & 12,3 & 142,1 & $-39,6$ \\
\hline Guarapuava & 18,5 & 200,8 & 12,2 & 114,5 & 9,2 & 93,7 & 7,8 & 84,2 & $-58,1$ \\
\hline Pato Branco & 23,7 & 305,1 & 25,8 & 291,6 & 21,2 & 265,8 & 19,3 & 251 & $-17,7$ \\
\hline WEST & 9,3 & 84,1 & 14,4 & 110,5 & 15 & 114 & 17,9 & 138,6 & 64,9 \\
\hline Francisco Beltrão & 9,1 & 95,5 & 9,6 & 92,6 & 10,1 & 105,1 & 14,9 & 145,5 & 52,3 \\
\hline Foz do Iguaçu & 9,9 & 70,6 & 13,1 & 78 & 17 & 96,2 & 9,2 & 57 & $-19,3$ \\
\hline Cascavel & 8,6 & 76,3 & 17,2 & 115,6 & 15 & 98 & 19,8 & 137,5 & 80,3 \\
\hline Toledo & 10 & 104,5 & 17,5 & 172,6 & 18,9 & 181,1 & 27,2 & 246,7 & 136,2 \\
\hline NORTHWEST & 7,2 & 69,2 & 12 & 98,2 & 12,9 & 106,7 & 12,1 & 102 & 47,5 \\
\hline Campo Mourão & 12,6 & 111,1 & 19,7 & 160,4 & 20,6 & 186,9 & 15,9 & 138,3 & 24,5 \\
\hline Umuarama & 7,5 & 67,5 & 8,5 & 63,8 & 9,2 & 72,5 & 8,9 & 65,6 & $-2,8$ \\
\hline Cianorte & 3,6 & 43,3 & 15,6 & 152,9 & 17,4 & 124,8 & 13 & 90,8 & 109,8 \\
\hline Paranavaí & 19,1 & 160,2 & 26 & 196,1 & 22,9 & 173,2 & 14,1 & 117,8 & $-26,5$ \\
\hline Maringá & 1,3 & 13,2 & 3,3 & 27,8 & 5,9 & 49,6 & 10,5 & 94,2 & 615,9 \\
\hline NORTH & 6,7 & 66,4 & 12,3 & 104,8 & 10,9 & 91,2 & 8,1 & 67,6 & 1,8 \\
\hline Apucarana & 4,1 & 42,4 & 11,2 & 97,7 & 5,5 & 49,4 & 5,8 & 53,1 & 25,1 \\
\hline Londrina & 7,8 & 78,2 & 10,4 & 89,4 & 10 & 76,6 & 6,2 & 46,9 & -40 \\
\hline
\end{tabular}

continued... 


\begin{tabular}{|c|c|c|c|c|c|c|c|c|c|}
\hline \multirow{2}{*}{ Macro-region/health region } & \multicolumn{2}{|c|}{ 2000-2002(a) } & \multicolumn{2}{|c|}{ 2003-2005 } & \multicolumn{2}{|c|}{ 2006-2008 } & \multicolumn{2}{|c|}{$2009-2011^{(b)}$} & \multirow{2}{*}{$\begin{array}{c}\begin{array}{c}\text { Variation } \\
(\%) \text { b-a }\end{array} \\
\text { Rate }\end{array}$} \\
\hline & $\% *$ & Rate & $\% *$ & Rate & $\% *$ & Rate & $\% *$ & Rate & \\
\hline Cornélio Procópio & 8,8 & 87,9 & 14 & 117,5 & 14,1 & 145,9 & 8 & 85,3 & $-2,9$ \\
\hline Jacarezinho & 3,8 & 33,9 & 11,6 & 89,8 & 6,8 & 52 & 11 & 80,2 & 136,7 \\
\hline Ivaiporã & 8,2 & 79,4 & 22,3 & 213,6 & 26,5 & 262,9 & 18 & 172,5 & 117,4 \\
\hline PARANÁ & 8,2 & 72,6 & 11,6 & 86,6 & 11,3 & 83,7 & 9,9 & 78,9 & 8,7 \\
\hline
\end{tabular}

* Proportion of total admissions due to all causes in each macro-region and health region.

Source: Brazilian Ministry of Health. Unified Health System Hospital Information System. DATASUS

The highest hospital admission rate was found in Central-South macro-region. However, this rate decreased significantly from $235.2 / 10,000$ inhabitants in the first three-year period to $142.1 / 10,000$ inhabitants in the last three-year period, equivalent to an overall reduction of $39.6 \%$, while the proportion of ACSC admissions in the Campos Gerais macro-region increased by 65.3\% (Table 4).

\section{DISCUSSION}

Given their vulnerability to catching diseases and developing complications, children are often the target of specific health policies, programmes and goals aimed at improving quality of life and reducing child morbimortality ${ }^{(12)}$. This study focused on admissions for ACSCs, which constitutes a key public health indicator.

However, to undertake an adequate analysis of ACSC admissions it is essential to identify the factors driving ACSCs such as the role of individual and family characteristics, environmental factors and use of health services. A study carried out in Australia showed that socioeconomic factors and access to care services influenced ACSC admissions among children ${ }^{(7)}$. The lack of information on factors that influence admissions - such as the socioeconomic status of care users, access to primary care and the hospital network, and the work processes of the health teams - limits the effectiveness of any analysis of this issue and hinders the comparison of results with other relevant studies.

It is also important to consider regional patterns, since there are a number of underlying socioeconomic disparities and differences in geographical and environmental factors between regions which may influence the health of the population. For example, the climate of the Centro-South region is cold and humid, while in the North region it is hot and dry. Climatic factors affect the vulnerability of children to specific diseases, therefore creating different demands according to region.

Furthermore, economic growth, social development and PHC coverage varied according to health region during the period studied. For example, while population coverage by the Family Health Strategy (ESF, acronym in Portuguese) in Paraná increased from $22.8 \%$ in the beginning of the study period to $56.1 \%$ in $2011^{(13)}$, the expansion of coverage differed across regions. Expansion was greatest in municipalities in the Northwest region, while the slowest expansion of coverage was in the Campos Gerais region ${ }^{(13)}$.
Therefore any in-depth discussion requires a prior analysis of these differences.

It should also be highlighted that this study used secondary data from the SIH-SUS, which may contain nonidentified errors. Although studies based on secondary data are critically important, it is important to consider that financial resources for hospital admissions are made available based on the content of hospital admission authorisation forms completed through decentralised procedures. A study which aimed to assess the reliability of SIH-SUS data by comparing data with information on the patient forms suggested that $20 \%$ of ACSC admissions were not recorded ${ }^{(3)}$. However, a number of studies have highlighted the importance of investigations based on data from the SIH-SUS and consider the system an important source of data for assessing $\mathrm{PHC}(2,6,10)$.

The results of this study show that the proportion of hospital admissions in children under five years of age over the twelve-year period in the State of Parana due to ACSC was $10.2 \%$; less than that observed by a study carried out in the State of Minas Gerais, which showed that ACSC admissions accounted for $41.4 \%$ of overall admissions ${ }^{(14)}$. In the Northeast region, ACSC admissions accounted for $60 \%$ of overall admissions in children under five years of age in $2010^{(10)}$.

Between the first and last three-year period, there was an increase in both ACSC admissions and overall admissions among children under the age of one, while in children aged between one and four years there was an increase in ACSC admissions and a decrease in overall admissions. These results corroborate the findings of a study carried out in the State of Piauí ${ }^{(10)}$.

The rate of ACSC admissions increased in all age groups, showing a marked increase (200\%) among children under the age of one. Despite the low prevalence of ACSC admissions in this age group, this increase is of concern given that, from birth, infants are the target of a number of health policies and child health monitoring and promotion programmes ${ }^{(12)}$. Admissions among children under the age of one are generally due to problems in the quality of prenatal care, which is part of primary health care, but are also related to birth and new born care which fall under hospital care ${ }^{(10)}$. Nevertheless, perinatal conditions, which account for a large part of admissions among children under the age of one, may be considered potentially avoidable ${ }^{(2)}$. 
The highest rates of ACSC admissions were found in the one to four-year age group. However, the fact that there was a reduction in overall admissions raises a question regarding the increase in the proportion of ACSCs in this age group in the State of Paraná. Possible explanations include barriers to primary health care and lack of capacity of health facilities, which are factors that negatively affect children's health ${ }^{(15)}$. Another factor worth noting is the approach to child health care in this age group adopted by health professionals, who tend to focus on children under the age of one. Even after the first year of life, the health of children should be accompanied since they are still physiologically vulnerable to environmental factors and family socioeconomic status.

A study conducted in Brazil's North Region showed the lack of monitoring of child growth and development - an important indicator of child health - and that the absence of this measure shows a discrepancy between child health care policies and practice ${ }^{(16)}$. Furthermore, one of the functions of the health team is to ensure continuity and comprehensiveness of care based on the empowerment of the family for child care, with the aim of making a positive impact on determinants of the health-disease process ${ }^{(12)}$.

Health promotion and disease prevention actions must be specific, taking into account the particular characteristics of each stage of life, rather than generalised. The present study observed that the five most common conditions (bacterial pneumonia, gastroenteritis, asthma, kidney and urinary tract infection, and nutritional deficiencies) accounted for $95.6 \%$ of ACSC admissions in children under five years of age. The fact that admissions were concentrated in only five of the 19 conditions shows the particular characteristics of this age group ${ }^{(9)}$.

The main cause of ACSCs in children can be found in the environment, the care provided by the child's family, and the vulnerability of the child's immune system ${ }^{(17)}$; as opposed to adults were causes are more diversified and vary according to age and lifestyle ${ }^{(18)}$. The prevalence of admissions due to different ACSCs is therefore different among children when compared to other age groups ${ }^{(1)}$. Bacterial pneumonia, gastroenteritis and kidney and urinary tract infection were the three most prevalent conditions among all age groups throughout the entire study period. These results corroborate the findings of a study which analysed the patient forms of children under five years of age admitted to a university hospital in the Northwest of the State of Paraná between 2004 and $2009{ }^{(19)}$.

Gastroenteritis, pneumonia and kidney and urinary tract infection are typical diseases in this age group, particularly among children aged under three years who are most vulnerable to these conditions ${ }^{(19)}$. Primary health care professionals should promote and monitor prevention measures of diseases which are prevalent among children, such as recommending breastfeeding as a protective factor against respiratory problems ${ }^{(20)}$. The health team should also promote continuity by making return appointments and home visits according to the child's health needs, to increase the effectiveness of care, avoid disease and prevent hospital admissions ${ }^{(12)}$.

Respiratory problems, infectious diseases and nutritional deficiencies should be easily identifiable by health teams since they are prevalent diseases among children. Gastroenteritis is one of the leading causes of child morbidity globally. However, $64.5 \%$ of cases are mild, $34.7 \%$ moderate, and only $0.5 \%$ severe, and therefore in the majority of cases admission is preventable through adequate primary care ${ }^{(21)}$.

Nutritional deficiencies were one of the main causes of admissions among children aged between one and four years. This may be due to a decrease in nutrition surveillance after the first year of life ${ }^{(22)}$. Children aged over one year are vulnerable to poor nutrition, as found by a study carried out in the State of Sergipe which showed a high prevalence of excessive sugar and fat consumption among children aged between two and three years ${ }^{(23)}$.

Family health education, adequate childcare and home visits can help the early diagnosis of these conditions and reduce inequalities in access to healthcare services. A study undertaken in Brazil's South Region which showed the importance of protecting and promoting the health of children observed that body weight was ideal according to age in $80.2 \%$ of children, and that $2.1 \%$ of children were at nutritional risk and $15.7 \%$ had mild malnutrition ${ }^{(22)}$.

The analysis of ACSCs by age group showed that there was a reduction in the proportion of admissions due to diseases related to the prenatal period and childbirth in children under the age of one, while in children aged between one and four years there was a reduction in the proportion of admissions due to nutritional deficiencies and asthma, showing that the impact of these causes on overall admissions declined. Generally, specific programmes exist for these types of conditions which contribute to a reduction in their complications and risk of hospital admission ${ }^{(24-25)}$. A study involving children with asthma and their families showed that asthma self-management education for the patient and their carers and stronger links between the family and primary healthcare team led to a $57 \%$ reduction in acute complications and a $74 \%$ decrease in admissions ${ }^{(25)}$.

A significant increase in the proportion of admissions due to diabetes mellitus was observed among children under the age of one. This is one of the most ambulatory common care-sensitive conditions and one of the most prevalent chronic diseases among children ${ }^{(26)}$, and should be identified and treated through primary healthcare ${ }^{(1)}$. A literature review suggested four important aspects for the effective management of chronic disease and subsequent prevention of admissions due to these conditions: the prevention services offered by the local health system, good access, adequate facilities, and organisation of the care process ${ }^{(27)}$.

Chronic diseases have a significant impact on the quality of life of patients and of their families. The lack of effective preventive health measures results in admissions to a hospital bed which could otherwise be used 
by patients with illnesses that demand intensive care, and an increase in costs to the local health network ${ }^{28-}$ ${ }^{29)}$. A study showed the high cost of admissions due to pneumonia in children to the health system, especially of recurrent admissions ${ }^{(30)}$.

An analysis of data by region showed that the proportion of admissions accounted for by ACSCs increased in half of the health regions. A discussion of the causes of this increase is important given the expansion of coverage of PHC in the State Paraná, principally through the implementation and expansion of the coverage of the ESF ${ }^{(13)}$. The increase in the proportion of ACSC admissions, despite the increase in coverage of PHC, suggests possible difficulties in accessing healthcare services and the lack of adequate and timely child health care, both of which are essential elements of admission prevention ${ }^{(7,15)}$. Conversely, a study carried out in the Northeast of Brazil observed an increase in coverage and reduction in ACSC admissions among children under five years of age (10), suggesting that the expansion of PHC contributes to a reduction in ACSC admissions. In São Paulo, there was a fall in ACSC admissions among the general population in 14 of the 17 health regions during the period 2000 to $2007^{(5)}$.

\section{CONCLUSION}

The results of this study, based on data on hospital admissions available from the Unified Health System Hospital Information System, provide a view of potentially avoidable admissions among children under five years of age in the State of Paraná during the period 2000 to 2011. The principal causes of admissions in this age group were pneumonia, gastroenteritis and asthma. The proportion of admissions accounted for by ACSCs was highest among children aged between one and four years, which reinforces the need for permanent education for ESF teams to achieve more effective care in accordance with the precepts of policies that address the health care needs of children and child health surveillance.

The proportion of admissions accounted for by ACSCs increased in half of the health regions in the State of Paraná. This fact may be related to socioeconomic and climatic differences, funding constraints, and lack of capacity of PHC teams to effectively solve health problems.

Finally, by identifying the types of ambulatory care sensitive conditions and trends in ACSC admissions, this study provides important knowledge to guide specific and effective actions within primary health care that contribute towards the prevention of admissions for ambulatory care sensitive conditions among children under five years of age.

\section{RESUMO}

Objetivo: Descrever as internações por condições sensíveis à atenção primária em menores de cinco anos, no estado do Paraná, Brasil, segundo causas, grupo etário e Regional de Saúde de residência. Método: Foi realizado um estudo de séries temporais do tipo ecológico, com dados do Sistema de Informações Hospitalares do Sistema Único de Saúde (SUS) de 2000 a 2011. As causas foram agrupadas de acordo com a lista brasileira de condições sensíveis. Resultados: Houve aumento das taxas de hospitalização por condições sensíveis em todos os grupos etários, principalmente em menores de um ano, em 50\% das Regionais de Saúde. Pneumonias, gastrenterites e asma foram as principais causas de internação. As hospitalizações por pneumonias e gastrenterites, no total das hospitalizações, aumentaram. Conclusão: $\mathrm{O}$ aumento das internações revela a necessidade de planejar ações de acesso à atenção primária e tratamento eficaz das principais condições sensíveis visando prevenir a hospitalização infantil.

\section{DESCRITORES:}

Criança; Hospitalização; Atenção Primária à Saúde; Serviços de Informação; Saúde da Criança.

\section{RESUMEN}

Objetivo: Describir las hospitalizaciones en virtud de condiciones sensibles a la atención primaria en menores de cinco años, en el Estado de Paraná, Brasil, según las causas, el rango de edad y la Regional de Salud de residencia. Método: Se llevó a cabo un estudio de series temporales del tipo ecológico, con datos del Sistema de Informaciones Hospitalarias del Sistema Único de Salud (SUS) de 2000 a 2011. Las causas fueron agrupadas de acuerdo con el listado brasileño de condiciones sensibles. Resultados: Hubo incremento de los índices de hospitalización debido a condiciones sensibles en todos los rangos de edad, especialmente en menores de un año, en el 50\% de las Regionales de Salud. Neumonías, gastroenteritis y asma fueron las principales causas de estancias hospitalarias. Las hospitalizaciones por neumonías y gastroenteritis, en el total de las hospitalizaciones, aumentaron. Conclusión: El aumento de las estancias hospitalarias revela la necesidad de planificar acciones de acceso a la atención primaria y tratamiento eficaz de las principales condiciones sensibles con vistas a prevenir la hospitalización infantil.

\section{DESCRIPTORES:}

Niño; Hospitalización; Atención Primaria de Salud; Servicios de Información; Salud del Niño.

\section{REFERENCES}

1. Rehem TCMSB, Oliveira MRF, Amaral TCL, Ciosak SI, Egry EY. Hospitalisations for ambulatory care sensitive conditions in a Brazilian metropolis. Rev Esc Enferm USP. 2013;47(4):884-90.

2. Oliveira RR, Costa JR, Mathias, TAF. Hospitalization of children under five years of age due to avoidable causes. Rev Latino Am Enfermagem. 2012;20(1):135-42.

3. Rehem TCMSB, Oliveira MRF, Ciosak SI, Egry EY. Record of hospitalizations for ambulatory care sensitive conditions: validation of the hospital information system. Rev Latino Am Enfermagem. 2013;21(5):1159-64. 
4. Medeiros ARP, Larocca LM, Chaves MMN, Meier MJ, Wall ML. Epidemiology as a theoretical-methodological framework in the nurses' working process. Rev Esc Enferm USP. 2012;46( 6 ):1519-23.

5. Rehem TCMSB, Egry EY. Hospitalizações por condições sensíveis à atenção primária no estado de São Paulo. Ciênc Saúde Coletiva. $2011 ; 16(12): 4755-66$.

6. Moura BLA, Cunha RC, Aquino R, Medina MG, Mota ELA, Macinko J, et al. Principais causas de internação por condições sensíveis à atenção primária no Brasil: uma análise por faixa etária e região. Rev Bras Saúde Mater Infant. $2010 ; 10$ Supl.1: S83-S91.

7. Ansari Z, Haider SI, Ansari H, Gooyer T, Sindall C. Patient characteristics associated with hospitalisations for ambulatory care sensitive conditions in Victoria, Australia. BMC Health Serv Res. 2012;12:475.

8. Brasil. Ministério da Saúde; Secretaria de Atenção à Saúde. Portaria n. 221, de 17 de abril de 2008. Define a Lista Brasileira de Condições Sensíveis à Atenção Primária. Diário Oficial da União, Brasília, 18 abr. 2008. Seção 1, p. 70.

9. Alfradique ME, Bonolo PF, Dourado I, Lima-Costa MF, Macinko J, Mendonça CS, et al. Internações por condições sensíveis à atenção primária: a construção da lista brasileira como ferramenta para medir o desempenho do sistema de saúde (Projeto ICSAP- Brasil). Cad Saúde Pública. 2009;25(26):1337-49.

10. Barreto JOM, Nery IS, Costa MSC. Estratégia Saúde da Família e hospitalizações hospitalares em menores de 5 anos no Piauí, Brasil. Cad Saúde Pública. 2012;28(3): 515-26.

11. Brasil. Ministério da Saúde; Secretaria de Atenção à Saúde, Departamento de Regulação, Avaliação e Controle. Manual técnico operacional do sistema de informações hospitalares: orientações técnicas. Brasília; 2010.

12. Brasil. Ministério da Saúde; Secretaria de Atenção à Saúde, Departamento de Ações Programáticas Estratégicas. Agenda de compromissos para a saúde integral da criança e redução da mortalidade infantil. Brasília; 2004.

13. Brasil. Ministério da Saúde; Departamento de Atenção Básica, Portal da Saúde. Histórico da cobertura da Saúde da Família [Internet]. Brasília; 2014 [citado 2014 jul. 27]. Disponível em: http://dab.saude.gov.br/portaldab/historico_cobertura_sf.php

14. Caldeira AP, Fernandes VBL, Fonseca WP, Faria AA. Hospitalizações pediátricas por condições sensíveis à atenção primária em Montes Claros, Minas Gerais, Brasil. Rev Bras Saúde Mater Infant. 2011;11(1):61-71.

15. Butler DC, Thurecht L, Brown L, Konings P. Social exclusion, deprivation and child health: a spatial analysis of ambulatory care sensitive conditions in children aged 0-4 years in Victoria, Australia. Soc Sci Med. 2013;94:9-16.

16. Rocha ACD, Pedraza DF. Child growth monitoring in family health basic units in the municipality of Queimadas, Paraíba, Brazil. Texto Contexto Enferm. 2013;22(4):1169-78.

17. Bird SR, Noronha M, Kurowski W, Orkin C, Sinnott H. Integrated care facilitation model reduces use of hospital resources by patients with pediatric asthma. J Healthc Qual. 2012;34(3):25-33.

18. Junqueira RMP, Duarte EC. Hospitalizations due to ambulatory care-sensitive conditions in the Federal District, Brazil, 2008. Rev Saúde Pública. 2012;46(5):761-8.

19. Oliveira BRG, Viera CS, Furtado MCC, Mello DF, Lima RAG. Perfil de morbidade de crianças hospitalizadas em um hospital público: implicações para a Enfermagem. Rev Bras Enferm. 2012;65(4):586-93.

20. Boccolini CS, Boccolini PMM, Carvalho ML, Oliveira MIC. Padrões de aleitamento materno exclusivo e internação por diarreia entre 1999 e 2008 em capitais brasileiras. Ciênc Saúde Coletiva. 2012;17(7):1857-63.

21. Lamberti LM, Fischer W, Christa L, Black, RE. Systematic review of diarrhea duration and severity in children and adults in low- and middleincome countries. BMC Public Health. 2012;12: 276.

22. Gauterio DP, Irala DA, Cezar-Vaz MR. Puericultura em enfermagem: perfil e principais problemas encontrados em crianças menores de um ano. Rev Bras Enferm. 2012;65(3):508-13.

23. Filha EOS, Araújo JS, Barbosa JS, Gaujac DP, Santos CFS, Silva DG. Consumo dos grupos alimentares em crianças usuárias da rede pública de saúde do município de Aracaju, Sergipe. Rev Paul Pediatr. 2012;30(4):529-36.

24. Reindal L, Oymar K. Hospital admissions for wheezing and asthma in childhood--are they avoidable? J Asthma. $2006 ; 43(10): 801-6$.

25. Becker DJ, Blackburn JL, Kilgore ML, Morrisey MA, Sen B, Caldwell C, et al. Continuity of insurance coverage and ambulatory care-sensitive hospitalizations/ED visits: evidence from the children's health insurance program. Clin Pediatr (Phila). 2011;50(10): 963-73.

26. Giralt Muiña P, Ballester Herrera MJ, Palomo Atance E, Angulo Donado JJ. Sánchez G, Santillana Ferrer L. Estudio epidemiológico de la diabetes tipo 1, en menores de 15 años en Castilla-La Mancha. An Pediatr (Barc). 2012;76(2):83-91.

27. Van Loenen T, Van den Berg MJ, Westert GP, Faber MJ. Organizational aspects of primary care related to avoidable hospitalization: a systematic review. Fam Pract. 2014;31(5):502-16.

28. Sheridan A, Howell F, Bedford D. Hospitalisations and costs relating to ambulatory care sensitive conditions in Ir J Med Sci. 2012;181(4):527-33.

29. Lu S, Kuo DZ. Hospital charges of potentially preventable pediatric hospitalizations. Acad Pediatr. 2012;12(5):436-44.

30. Neuman MI, Hall M, Gay JC, Blaschke AJ, Williams DJ, Parikh K, et al. Readmissions among children previously hospitalized with pneumonia. Pediatrics. 2014;134(1):100-9. 